\title{
The Possible Protective Role of Ginger against Carbon Tetrachloride-Induced Nephrotoxicity in Rats. Histopathological and Morphometric Study
}

\author{
Ahmad A. El-Ebiary, Arwa A. Abuelfadl', Ehab M. Hantash'2, \\ Ahmed A. Abdalfattah ${ }^{3}$, Ahmed A.M. Abdelmotelb and Sabah El-Ghaiesh ${ }^{4}$
}

\author{
${ }^{1}$ Departments of Forensic Medicine and Clinical Toxicology \\ ${ }^{2}$ Departments of Anatomy \\ ${ }^{3}$ Departments of Physiology \\ ${ }^{4}$ Departments of Pharmacology
}

Faculty of Medicine, Tanta University, Tanta, Egypt.

\begin{abstract}
Carbon tetrachloride $\left(\mathrm{CCl}_{4}\right)$ has long been known as a model toxicant. Several reports have discussed its toxic effects on different organs by inducing oxidative stress and free radical production. A number of antioxidant agents, including herbal extracts, have been reported to reduce $\mathrm{CCl}_{4}$ induced toxicity. Many studies have reported the beneficial effects of ginger including its antioxidant properties. This work was performed to assess the possible protective role of ginger against $\mathrm{CCl}_{4}$ induced renal injury in adult male albino rats. A total of 48 adult male rats were divided into 3 groups. Group I served as the control group. Group II received $\mathrm{CCl}_{4}$ by intraperitoneal injections, twice weekly, for 4 weeks. Group III received $\mathrm{CCl}_{4}$ (as previously described) and aqueous extract of ginger orally, once daily, for 4 weeks. At the end of the experiment, renal specimens were processed for light and electron microscopic examination. In addition, morphometric analysis was performed on electromicrographs to assess the filtration barrier integrity. Carbon tetrachloride treated rats showed renal corpuscles with shrunken, lobulated, and hypercellular glomeruli, podocyte affection, as well as mesangial cell proliferation. Morphometric analysis demonstrated disordered filtration barrier integrity. The use of ginger prevented most of these structural changes. Exposure to $\mathrm{CCl}_{4}$ resulted in nephrotoxicity associated with glomerular and tubular alterations in adult male rats. Ginger exhibited a protective effect against $\mathrm{CCl}_{4}$ induced renal damage.
\end{abstract}

Keywords Carbon tetrachloride, nephrotoxicity, ginger, rat, glomerular filtration integrity.

\section{Introduction}

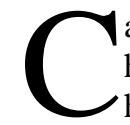
arbon tetrachloride is a well-known, potent hepatotoxin (Xiao et al., 2012). Recent studies than the liver such as the brain, heart, lung and kidneys. The mechanism of $\mathrm{CCl}_{4}$ induced toxicity includes production of free radicals, which induce lipid peroxidation, besides the activation of tissue macrophages associated with the production of inflammatory mediators (Mourad et al., 2006; Jayakumar et al., 2008).
The implication of oxidative stress and inflammation in the etiology and progression of many clinical disorders has led to the suggestion that agents with antioxidant and anti-inflammatory properties may have health benefits. Several antioxidant agents, including herbal extracts, antioxidant vitamins and melatonin have been reported to reduce $\mathrm{CCl}_{4}$-induced toxicity (Donder et al., 1999; Turkdogan et al., 2001; Shaker et al., 2011). Zingiber officinale Roscoe (Zingiberaceae) is one of the most widely used spices 
worldwide. It has an analgesic and anti-inflammatory properties (Jagetia et al., 2003), and it has been reported as an antioxidant and detoxifying agent against alcohol abuse and bromobenzene intoxication (El-Sharaky et al., 2009; Shati and Elsaid, 2009). In addition, the protective effect of ginger was reported against carbon tetrachloride and 6-mercaptopurin induced hepatic damage (Abd-El Aty and Morgan, 2011; Hamed et al., 2012).

Maintaining the balance between free radicals and antioxidants, besides inhibiting the production of inflammatory mediators may serve as major mechanisms in preventing damage induced by this toxic agent. Hence, the major aim of the present study was to assess the potential protective role of ginger on renal corpuscles of $\mathrm{CCl}_{4}$-intoxicated adult male rats.

\section{Materials and methods}

\section{Chemicals}

Carbon tetrachloride solution was purchased from Sigma Co., St. Louis, USA. Ginger tablets were provided by Pharco-pharmaceutical Company, Alexandria, Egypt.

\section{Animals}

The study protocol was approved by the Research Ethics Committee of the Faculty of Medicine, Tanta University, Egypt. Anesthetic procedures and handling with animals complied with the ethical guidelines of the Research Ethics Committee. Forty eight adult male albino rats, weighing from 180 to $220 \mathrm{gm}$ were used in this study. Animals were housed under standard conditions of temperature $\left(23 \pm 2{ }^{\circ} \mathrm{C}\right)$ and lighting $(12 \mathrm{~h} \mathrm{light/dark}$ cycles) and were allowed free access to food and drinking water.

\section{Experimental design}

Group I (Control group): It included 24 rats that were further subdivided into 3 equal subgroups (8 rats each). Subgroup (i) was kept without treatment throughout the study. Subgroup (ii) received $0.5 \mathrm{ml}$ of olive oil (diluting vehicle for $\mathrm{CCl}_{4}$ ) by intraperitoneal injections, twice weekly, for 4 weeks. Subgroup (iii) received $1 \mathrm{ml}$ of aqueous extract of ginger (100 mg/kg body weight) by gavage, once daily, for 4 weeks (El-Sharaky et al., 2009). Group II $\left(\mathrm{CCl}_{4}\right.$ treated group): included 12 rats that received intraperitoneal injections of $0.5 \mathrm{ml}$ of $\mathrm{CCl}_{4}$ diluted 1:1 (v/v) in olive oil, twice weekly, for 4 weeks (Marsillach et al., 2009).

Group III ( $\mathrm{CCl}_{4} \&$ Ginger treated group): included 12 rats that received $\mathrm{CCl}_{4}$ and ginger as previously described.

By the end of the experiment, the animals were anesthetized by ether and sacrificed by decapitation and a median abdominal incision was made to deliver the kidneys.

\section{Histopathological examination}

For light microscopic study, specimens were taken from the upper pole of the right kidney and were fixed in 10\% formalin for preparation of paraffin blocks. Five $\mu \mathrm{m}$ sections were cut and stained by hematoxylin and eosin
(H\&E) (Gamble, 2008). For electron microscopic examination, $\left(1 \mathrm{~mm}^{3}\right)$ renal cortical pieces were immediately fixed in $2.5 \%$ phosphate buffered gluteraldehyde $\left(\mathrm{pH} \mathrm{7.4)}\right.$ at $4^{\circ} \mathrm{C}$ for 24 hours and post fixed in $1 \%$ osmium tetraoxide for one hour, then dehydrated in ascending grades of ethanol. After immersion in propylene oxide, the specimens were embedded in epoxy resin mixture. Ultrathin sections (80$90 \mathrm{~nm}$ ) were stained with uranyl acetate and lead citrate, and were examined and photographed with a JEOL transmission electron microscope in EM Unit, Faculty of Medicine, Tanta University (Woods and Stirling, 2008).

\section{Morphometric study and statistical analysis}

Morphometric analysis was performed to evaluate four criteria for filtration barrier integrity; the thickness of glomerular basement membrane (BM), foot process base width, slit pore diameter and number of slit pores. This was done in EM unit (Faculty of Medicine, Tanta University) on the TEM images of $80 \mathrm{kV}$ to analyze the number of slit pores per $100 \mu \mathrm{m}$ of glomerular BM and also to measure the slit pore diameter, the BM thickness and foot process base width at the glomerular BM. Five measurements were performed for each variable per image for each ultrathin section of each group (WhaleyConnell et al., 2006). Values were represented as means and standard deviations. As regards control subgroups, their means and standard deviations were represented in one value of the control group. Statistical analysis was performed using Analysis of variance (ANOVA) test, where the results were considered statistically significant if $\mathrm{p}<0.05$.

\section{Results}

\section{I- Light microscopy}

Light microscopic examination of H\&E stained sections of renal cortex of control group shows renal corpuscles having glomeruli with normal cellularity, which are surrounded by capsular spaces and Bowman's capsule. Renal corpuscles are surrounded by many proximal convoluted tubules (PCT) lined by pyramidal cells, and distal convoluted tubules (DCT) lined by cubical cells. These cells have acidophilic cytoplasm and basophilic nuclei (Fig. 1).

Examination of renal cortical sections from $\mathrm{CCl}_{4}$ treated rats reveals several injured Malpighian corpuscles, which display shrunken, deeply stained glomeruli with widening of the capsular spaces. The surrounding tubules appear dilated with irregular walls and shedding of the lining epithelium, besides pyknosis of their nuclei. The PCT brush borders are lost, with disruption of the tubular walls (Fig. 2).

Sections of renal cortex of the $\mathrm{CCl}_{4}$ and ginger treated group show almost normal renal architecture. Most of the Malpighian corpuscles and the surrounding PCT and DCT have the same features of the control group (Fig. 3). 


\section{II- Electron microscopy}

Electron microscopic examination of ultrathin sections of renal cortex of control group reveals podocytes with central nuclei and characteristic primary processes and secondary small foot processes, which are seen regularly spaced and resting on the glomerular basement membrane of blood capillaries. These processes are separated from each other by filtration slits and covered by slit diaphragm. The basal lamina show regular thickness. Mesangial cells are characterized by kidney shaped nuclei surrounded by electron dense cytoplasm and embedded in the thick mesangial matrix. These cells are seen supporting the wall of the glomeruli where podocyte foot processes are absent (Fig. 4).

Ultrathin sections of $\mathrm{CCl}_{4}$ treated rats show podocytes with disrupted plasma membrane and cytoplasmic rarefaction, together with few normal regularly spaced secondary foot processes. Some foot processes are swollen, disrupted or completely lost. Major foot processes display vacuoles. The glomerular basal lamina show irregular thickening. As well, increase in the number of glomerular mesangial cells is observed (Fig. 5).

Regarding ginger and $\mathrm{CCl}_{4}$ treated group, their ultrathin sections disclose podocytes with normal euchromatic nuclei and uniform width of basal lamina of capillary endothelium. It is enveloped with many regularly spaced normal looking foot processes (Fig.6).

\section{III- Morphometric analysis}

Indicators of glomerular filtration barrier integrity were significantly influenced in the $\mathrm{CCl}_{4}$ treated group as compared to the control group. Basement membrane thickness, podocyte foot process base width and slit pore diameter were significantly increased in rats treated with $\mathrm{CCl}_{4}$, but animals treated with both ginger and $\mathrm{CCl}_{4}$ showed insignificant difference compared to those of the control group. The number of slit pores per 100 um of $\mathrm{BM}$ was significantly decreased in $\mathrm{CCl}_{4}$ treated group, yet the group treated with ginger and $\mathrm{CCl}_{4}$ showed normalization in this parameter (Table 1).

Table 1. ANOVA one way statistical analysis of the basement membrane thickness, foot processes base width, slit pore diameter and number of slit pores per $100 \mathrm{um}$ of the basement membrane in the studied groups.

\begin{tabular}{|l|c|c|c|c|c|c|c|}
\hline & Control group & $\mathbf{C C l}_{4}$ group & $\begin{array}{c}\mathbf{C C l}_{4} \text { \& Ginger } \\
\text { group }\end{array}$ & $\mathbf{f}$ & $\mathbf{p}$ & $\mathbf{p 1}$ & $\mathbf{p 2}$ \\
\hline BM thickness (um) & $0.324 \pm 0.056$ & $0.651 \pm 0.369$ & $0.379 \pm 0.081$ & 4.512 & $0.001^{*}$ & $0.009^{*}$ & 0.063 \\
\hline $\begin{array}{l}\text { Foot processes base } \\
\text { width (um) }\end{array}$ & $0.238 \pm 0.041$ & $0.442 \pm 0.283$ & $0.268 \pm 0.042$ & 3.128 & $0.019^{*}$ & $0.014^{*}$ & 0.071 \\
\hline Slit pore diameter (um) & $0.017 \pm 0.012$ & $0.062 \pm 0.030$ & $0.025 \pm 0.021$ & 4.329 & $0.007^{*}$ & $0.006^{*}$ & 0.078 \\
\hline $\begin{array}{l}\text { Number of slit } \\
\text { pores/100 um of BM }\end{array}$ & $416.666 \pm 146.391$ & $216.666 \pm 113.689$ & $316.666 \pm 171.241$ & 5.644 & $0.006^{*}$ & $0.001^{*}$ & 0.059 \\
\hline
\end{tabular}

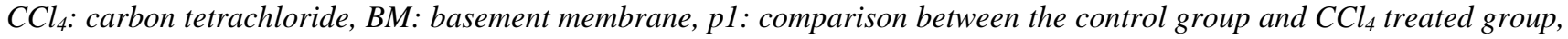
p2: comparison between the control group and $\mathrm{CCl}_{4} \&$ ginger treated group, *significant at $p<0.05$

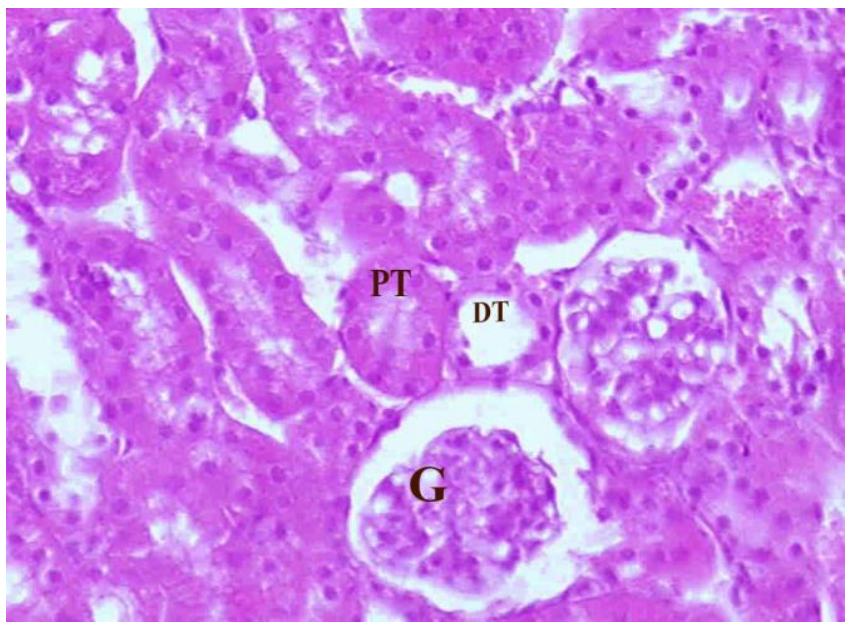

Fig. 1: Photomicrograph of a renal cortex of the control group showing normal looking Malpighian corpuscles (G). Notice proximal (PT) and distal convoluted tubules (DT).

(H\&E, Mic. Mag. X 400)

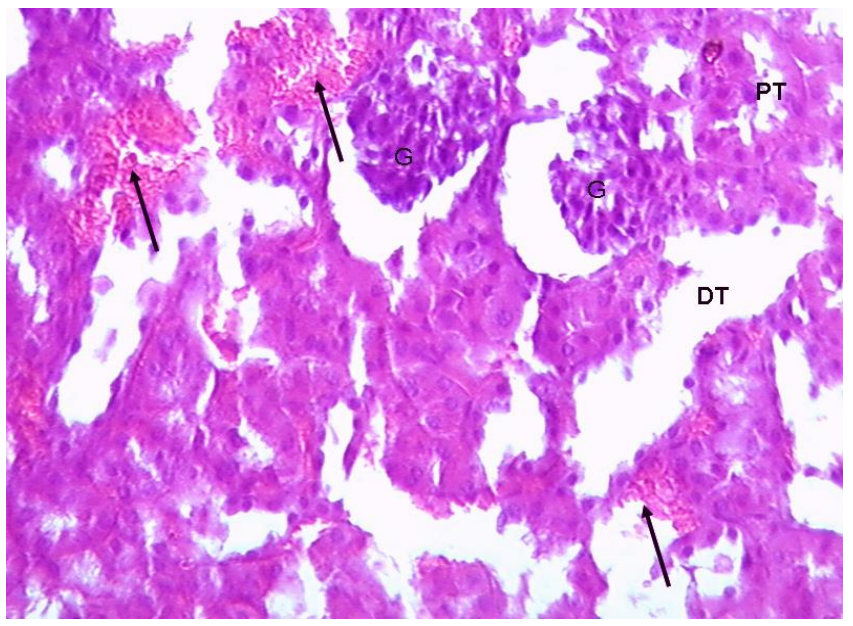

Fig. 2: Photomicrograph of a renal cortex of the $\mathrm{CCl}_{4}$ treated group showing loss of architecture with interstitial hemorrhage $(\rightarrow)$. Malpighian corpuscles display shrunken glomeruli (G) with widening of the capsular space. The surrounding proximal (PT) and distal (DT) tubules are dilated with irregular wall and shredded epithelium in association with pyknosis of their nuclei. (H\&E, Mic. Mag. X 400) 


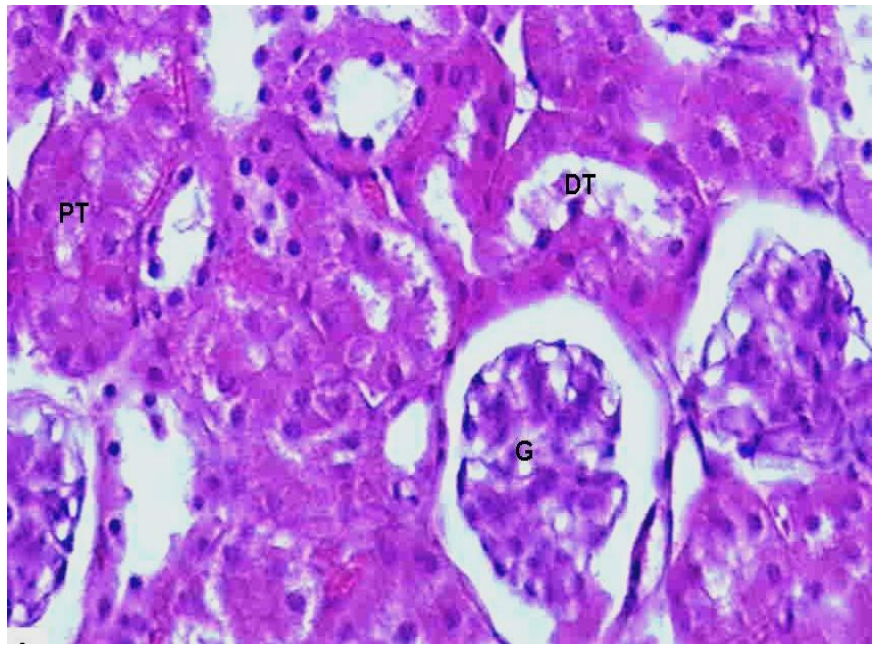

Fig. 3: Photomicrograph of a renal cortex of the $\mathrm{CCl}_{4}$ and ginger treated group showing normal looking Malpighian corpuscles (G) and normal proximal (PT) and distal (DT) tubules.

(H\&E, Mic. Mag. X 400)

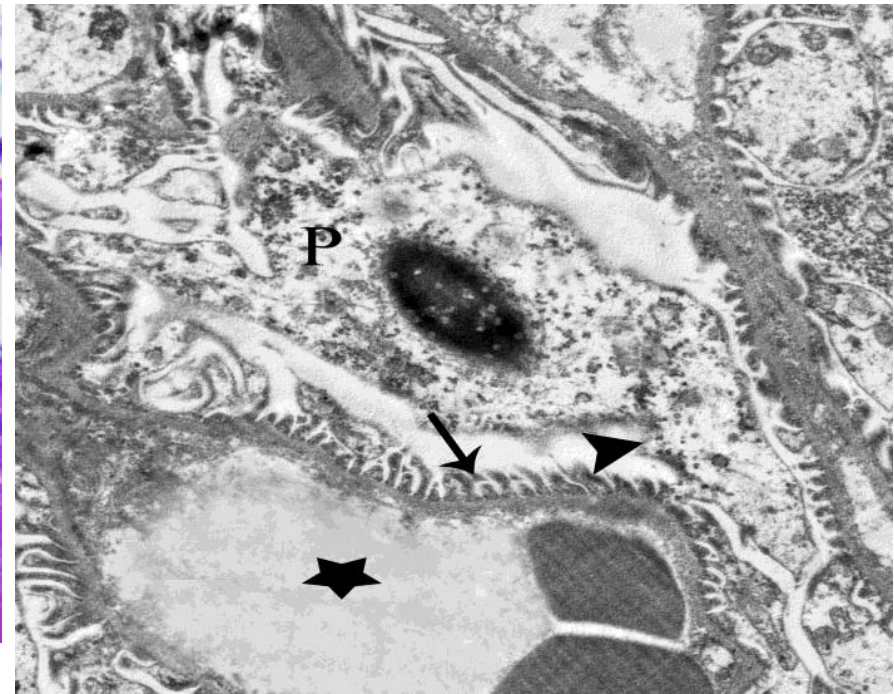

Fig. 4: Electron micrograph of ultrathin section of renal cortex of control group showing podocyte (P) with central nucleus and characteristic well-formed primary process $(\triangleright)$ and secondary small foot processes $(\rightarrow)$ resting on the glomerular basement membrane of blood capillary (*). The basal lamina shows regular thickness. (Mic. Mag. X 2500)

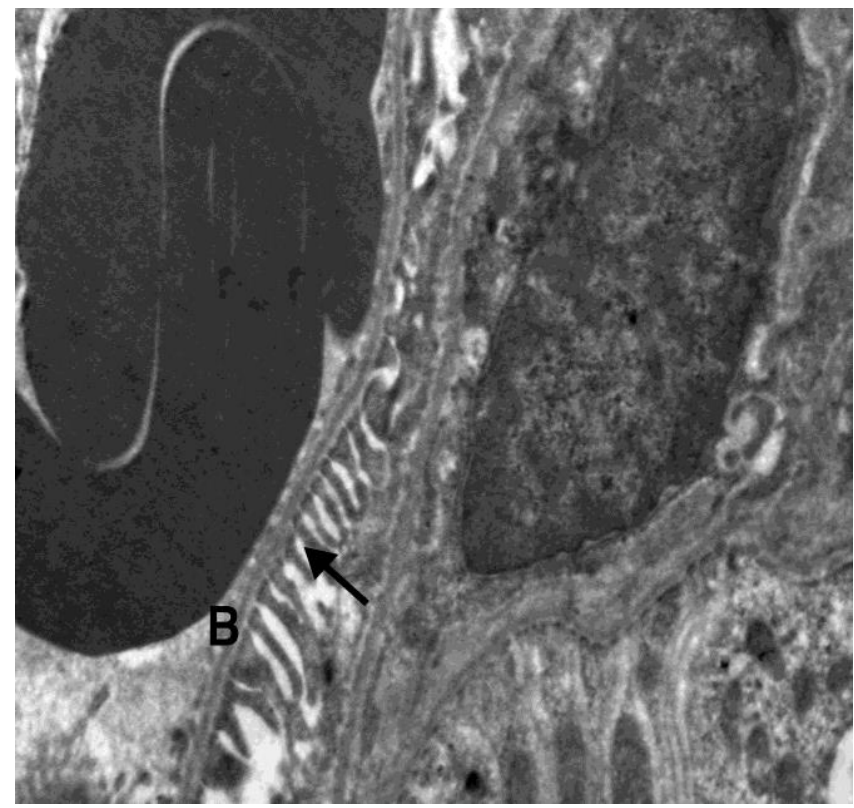

Fig. 6: Electron micrograph of ultrathin section of renal cortex of $\mathrm{CCl}_{4}$ and ginger treated group showing podocyte with normal nucleus, uniform width of basal lamina of capillary endothelium (B), which is enveloped with many regularly spaced normal looking foot processes $(\rightarrow)$.

(Mic. Mag. X 3000) The basal lamina shows irregular thickening. (Mic. Mag. X 5000) 


\section{Discussion}

The present work revealed that $\mathrm{CCl}_{4}$ induced manifest structural and ultrastructural changes associated with disordered glomerular filtration barrier integrity in the renal corpuscles of adult male rats. Shrunken hypercellular glomeruli with thickening of the glomerular basement membrane and podocyte ultrastructural changes were all evident. Mostly these changes were prevented when animals were treated with ginger along with $\mathrm{CCl}_{4}$.

Glomerular sclerosis found in the present study was reported also by other researchers (Doğukan et al., 2003; Ganie et al., 2011). Similar findings associated with significant alterations in antioxidant enzyme activities were shown, indicating the occurrence of oxidative stress and increase in free radical production (Ozturk et al., 2003). Carbon tetrachloride induced nephrotoxicity was assumed to be secondary to liver impairment, as cirrhotic rats with $\mathrm{CCl}_{4}$ induced liver damage exhibited manifest renal structural changes associated with significant reduction of renal functions (Rincón et al., 1999). However, renal damage might develop independently of hepatic involvement, with oxidative stress and generation of reactive oxygen species (ROS) as one of the suggested mechanisms for $\mathrm{CCl}_{4}$ induced nephrotoxicity. Carbon tetrachloride was shown to enhance the generation of ROS, which may provoke membrane lipid peroxidation of the endoplasmic reticulum, leading to disturbed $\mathrm{Ca}^{2+}$ homeostasis and finally cell death. This could explain the atrophied glomeruli and disrupted plasmalemma of the parietal layer of Bowman's capsule and of podocytes observed in this study (Duque et al., 1992; Abraham et al., 1999; Adewole et al., 2007).

Glomerular collapse and widening of the capsular space reported in the current study may result from contraction of mesangial cells that is usually coupled with contraction of the basement membrane of glomerular capillary endothelium. Glomerular sclerosis may possibly be related to vasoconstriction secondary to the induction of oxidative stress and the subsequent release of vasoactive mediators. In addition, increased collagen production by mesangial cells plays a key role in the development and progression of glomerular sclerosis (Garcia-Cohen et al., 2000; Hamed et al., 2012).

Examination of the renal cortex of $\mathrm{CCl}_{4}$ treated rats showed hypercellular glomeruli, which was reported also by other studies (Rincón et al., 1999; JaramilloJuárez et al., 2008). The current study also revealed thickening of the basement membrane that was confirmed by morphometric analysis. This could be explained in light of the increased release of ROS, which provokes proliferation of mesangial cells. These cells are the major contributor of the extracellular matrix, which contains type IV collagen and fibronectins (Adewole et al., 2007; Dentelli et al., 2007).
Corresponding to the results of Ogata et al. (1995) the present study revealed lots of seriously affected podocytes with effacement of their foot processes in the renal cortex of $\mathrm{CCl}_{4}$ treated rats. Podocyte structural changes may result in retraction of their foot processes, increased permeability of the glomerular filtration barrier and proteinuria along with deterioration of the renal functions (Pavenstädt et al., 2003).

The present study showed normal appearance of most Malpighian corpuscles associated with average filtration barrier integrity parameters in rats treated with both $\mathrm{CCl}_{4}$ and ginger. Other researchers reported comparable results. The favorable effect of ginger was assumed to be due to its ability to enhance the activities of antioxidant enzymes and to reduce inflammation and improve kidney function. Moreover, ginger is rich in natural antioxidants, and it can clean up free radicals generated by $\mathrm{CCl}_{4}$ (Stoilova et al., 2007; Hamed et al., 2012).

From the present study, it could be concluded that $\mathrm{CCl}_{4}$ has a toxic effect on the glomerular filtration barriers of adult male albino rat kidney, which was largely prevented by concomitant administration of ginger.

\section{References}

Abd-El Aty OA and Morgan EN (2011): Ginger administration has a protective effect on the liver of albino rats treated with 6-mercaptopurin. J. Am. Sci. 7:183-190.

Abraham P, Wilfred G and Cathrine SP (1999): Oxidative damage to the lipids and proteins of the lungs, testis and kidney of rats during carbon tetrachloride intoxication. Clin. Chim. Acta. 289:177-179.

Adewole SO, Salako AA, Doherty OW et al., (2007): Effect of Melatonin on carbon tetrachlorideinduced kidney injury in Wistar rats. Afr. J. Biomed. Res. 10:153-164.

Dentelli P, Rosso A, Zeoli A et al., (2007): Oxidative stress-mediated mesangial cell proliferation requires $\mathrm{RAC}-1 /$ reactive oxygen species production and $\beta 4$ integrin expression. J. Biol. Chem. 282:26101-26110.

Doğukan A, Akpolat N, Celiker H et al., (2003): Protective effect of interferon-alpha on carbon tetrachloride-induced nephrotoxicity. J. Nephrol. 16:81-84.

Donder E, Baydas G, Ozkan Y et al., (1999): Investigation of antioxidant effect of melatonin against carbon tetrachloride toxicity in various tissues. Biomed. Res. 10:141-145.

Duque I, Garcia-Escribano C, Rodriguez-Puyol M et al., (1992): Effects of reactive oxygen species on 
cultured rat mesangial cells and isolated rat glomeruli. Am. J. Physiol. 263:F466-F473.

El-Sharaky AS, Newairy AA, Kamel MA et al., (2009): Protective effect of ginger extract against bromobenzene-induced hepatotoxicity in male rats. Food Chem. Toxicol. 47:1584-90.

Gamble M (2008): The Hematoxylins and Eosin. In: Theory and Practice of Histological Techniques, Bancorft JD and Gamble M (eds), $6^{\text {th }}$ ed., Churchill Livingstone, New York USA, pp. 121-134.

Ganie SA, Haq E, Hamid A et al., (2011): Carbon tetrachloride induced kidney and lung tissue damages and antioxidant activities of the aqueous rhizome extract of Podophyllum hexandrum. BMC Complement Altern. Med. 11:17.

Garcia-Cohen E-C, Marin J, Diez-Picazo LD et al., (2000): Oxidative stress induced by tert-butyl hydroperoxide causes vasoconstriction in the aorta from hypertensive and aged rats: role of cyclooxygenase-2 isoform. J. Pharmacol. Exp. Ther. 293:75-81.

Hamed MA, Ali SA and Saba El-Rigal N (2012): Therapeutic potential of ginger against renal injury induced by carbon tetrachloride in rats. Sci. World J. Article ID 840421. 1-12.

Jagetia GC, Baliga MS, Venkatesh P et al., (2003): Influence of ginger rhizome (Zingiber officinale Rosc) on survival, glutathione and lipid peroxidation in mice after whole-body exposure to gamma radiation. Radiat. Res. 160:584-592.

Jaramillo-Juárez F, Rodríguez-Vázquez ML, RincónSánchez AR et al., (2008): Acute renal failure induced by carbon tetrachloride in rats with hepatic cirrhosis. Ann. Hepatol. 7:331-338.

Jayakumar T, Sakthivel M, Thomas PA et al., (2008): Pleurotus ostreatus, an oyster mushroom, decreases the oxidative stress induced by carbon tetrachloride in rat kidneys, heart and brain. Chem. Biol. Interact. 176:108-120.

Marsillach J, Camps J, Ferré N et al., (2009): Paraoxonase-1 is related to inflammation, fibrosis and PPAR delta in experimental liver disease. BMC Gastroenterol. 9:3.

Mourad GM, Takei El-Din SG, Radi SS et al., (2006): Curcumin versus Nigella sativa L. A comparative study of their possible protective effects on experimentally induced liver injury in rats. J. Med. Res. Inst. 27:141-151.
Ogata S, Takeda M, Lee M-J et al., (1995): Histopathological sequence of hepatic and renal lesions in rats after cessation of the repeated administration of $\mathrm{CCl}_{4}$. Exp. Toxicol. Pathol. 47:493-499.

Ozturk F, Ucar M, Ozturk IC et al., (2003): Carbon tetrachloride induced nephrotoxicity and protective effect of betaine in Sprague-Dawley rats. Urology 62:353-356.

Pavenstädt H, Kriz W and Kretzler M (2003): Cell biology of the glomerular podocyte. Physiol. Rev. 83:253-307.

Rincón AR, Covarrubias A, Pedraza-Chaverrí J et al., (1999): Differential effect of $\mathrm{CCl}_{4}$ on renal function in cirrhotic and noncirrhotic rats. Exp. Toxicol. Pathol. 51:199-205.

Shaker ME, Zalata KR, Mehal WZ et al., (2011): Comparison of imatinib, nilotinib and silymarin in the treatment of carbon tetrachloride-induced hepatic oxidative stress, injury and fibrosis. Toxicol. Appl. Pharmacol. 252:165-175.

Shati A and Elsaid FG (2009): Effects of water extracts of thyme (Thymus vulgaris) and ginger (Zingiber officinale Roscoe) on alcohol abuse. Food Chem. Toxicol. 47:1945-1949.

Stoilova I, Krastanov A, Stoyanova A et al., (2007): Antioxidant activity of a ginger extract (Zingiber officinale). Food Chem. 102:764-770.

Turkdogan MK, Agaoglu Z, Yener Z et al., (2001): The role of antioxidant vitamins ( $\mathrm{C}$ and $\mathrm{E}$ ), selenium and Nigella sativa in the prevention of liver fibrosis and cirrhosis in rabbits: new hopes. Dtsch. Tierarztl. Wochenschr. 108:71-73.

Whaley-Connell AT, Chowdhury NA, Hayden MR et al., (2006): Oxidative stress and glomerular filtration barrier injury: role of the reninangiotensin system in the Ren2 transgenic rat. Am. J. Physiol. Renal Physiol. 291:F1308F1314.

Woods AE and Stirling JW (2008): Electron Microscopy. In: Theory and Practice of Histological Techniques, Bancorft JD and Gamble M (eds), $6^{\text {th }}$ ed., Churchill Livingstone, New York USA, pp. 601-636.

Xiao J, Liong EC, Ching YP et al., (2012): Lycium barbarum polysaccharides protect mice liver from carbon tetrachloride-induced oxidative stress and necro-inflammation. J. Ethnopharmacol. 139:462-470. 
الملخص العربى

الدور الوقائي المحتمل للزنجبيل ضد تسمم الكلى الناجم عن رابع كلوريد الكربون في الجرذان: دراسة هستوباثولوجية و مورفومترية

أحمد عبد الستار الإبيارى و أروة أحمد أبو الفضل ا و إيهاب محمد هنشب و أحمد السبد عبدالفتاحr وأحمد عاصم عبدالمطلب وصباح حسين الغايش ع إن

يعتبر رابع كلوريد الكربون منذ زمن طويل نموذجا للتجارب و الدراسات السمية، وقد ناقشت العديد من التقارير

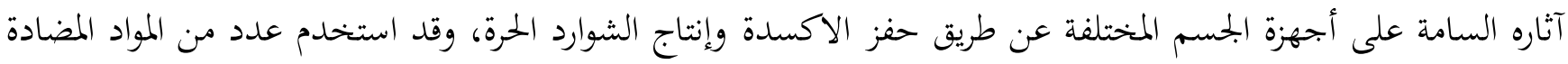

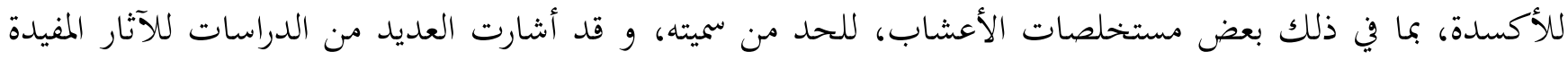

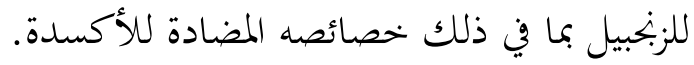

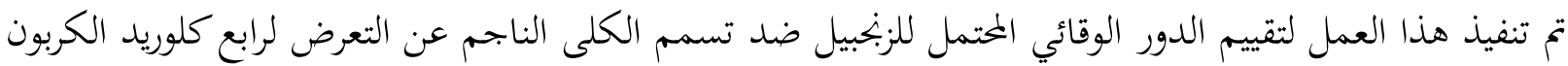
في ذكور الجرذان البيضاء.

تم تقسيم ثمانية و أربعين من ذكور الجرذان البيضاء البالغة إلى ثلاث الجيضاء بحموعات، المجموعة الأولى كانت بمثابة

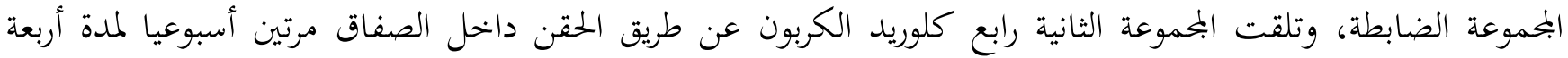

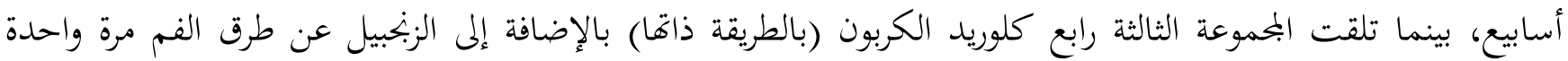

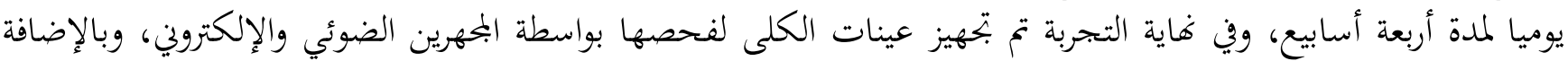

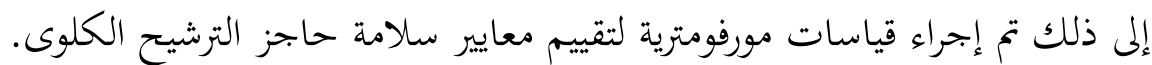

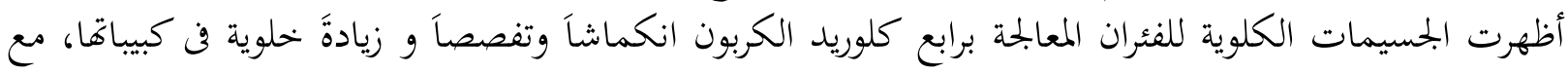

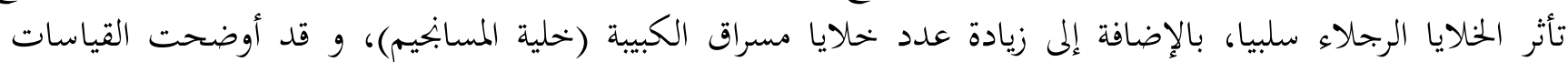

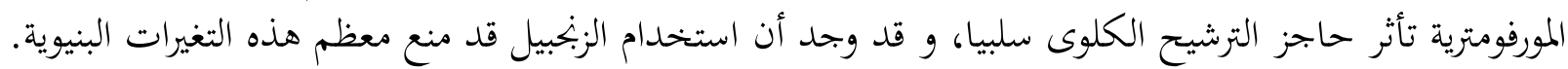

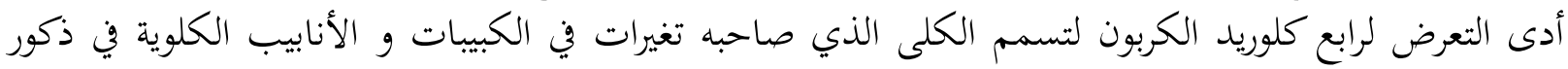
الجرذان البالغين، و كان للزبجبيل تأثير وقائي ضد الضرر الكلعيد النوبي الناجم عن رابع كلوريد الكربون.

\footnotetext{
ا قسم الطب الثرعي و السموم الإكلينيكية ـ كلية الطب - جامعة طنطا.

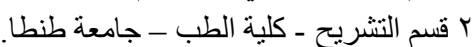

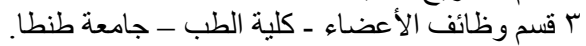
ع قسم الأدوية ـ كلية الطب - جامعة طنطا.
} 